\title{
Kuzeydoğu Anadolu Bölgesi ekolojik koşullarında yetişen bazı tıbbi bitkilerin biyokimyasal içeriği ve antioksidan özelliklerinin belirlenmesi
}

\author{
Zehra Tuğba MURATHAN * \\ Ardahan Üniversitesi, Mühendislik Fakültesi, Gıda Mühendisliği Bölümü 75000, Ardahan,Türkiye. \\ Gelis Tarihi (Recived Date): 27.12.2017 \\ Kabul Tarihi (Accepted Date): 04.09.2018
}

\section{Özet}

Türkiye coğrafik yapısı, iklimsel özellikleri ve konumundan ötürü çok zengin bir bitki örtüsüne sahiptir. Bu bitki çeşitliliğinin içerisinde çok sayıda tıbbi ve aromatik bitkiyi de barındırmaktadır. Bu çalışmada ülkemizin Kuzey Doğu Anadolu bölgesinde yer alan Ardahan ilinde yetişen, halk arasındaki adlarlyla kımı (Anthriscus sylvestris (L.) Hoffm.), madimak, (Polygonum cognatum Meissn.), evelik (Rumex crispus L.), aslan pençesi (Allcemilla sericata Rchb.) ve çuha (Primula veris L.) bitkilerinin bazı biyoaktif bileșen içerikleri ve antioksidan özellikleri belirlenmiștir. Bitkilerin yaprak örnekleri Mayıs ayında toplanarak laboratuvara getirilmiş ve taze örneklerle hazırlanan ekstraktlarla analizler gerçekleştirilmiştir. Çalışmada toplam fenolik madde ve toplam flavanoid madde içeriği ile 2,2'-azino-bis(3-ethylbenzothiazoline-6-sulfonic acid (ABTS) (\% 91,9), 2,2-diphenyl-1-picrylhydrazyl (DPPH) (\% 58.9) ve Demir(III) iyonu indirgeyici antioksidan gücü (FRAP) (770,8 $\mu \mathrm{mol} \mathrm{Fe} \mathrm{II/g)} \mathrm{metodlarına} \mathrm{göre} \mathrm{antioksidan}$ aktivitesi en yüksek olan bitkinin Allcemilla sericata Rchb. olduğu belirlenmiştir. Bitki türlerinin toplam askorbik asit içeriklerinin 118,5 ile 387,7 mg/100g değerleri arasında olduğu ve en yüksek değerin Anthriscus sylvestris (L.) bitkisinde olduğu tespit edilmiştir.

Anahtar kelimeler: Antioksidan, askorbik, fenolik, flavanoid, tıbbi bitki.

\section{Determination of the biochemical content and antioxidant properties of some medical plants grown in the North East} Anatolia Region ecological conditions

\footnotetext{
* Zehra Tuğba MURATHAN, ztugbaabaci@ hotmail.com, http://orcid.org/0000-0002-1468-7240
} 


\begin{abstract}
Turkey has a very rich vegetation, due to its geografic structure and climatic conditions. This plant diversity contains many medicinal and aromatic plants. In this study, it has been identified some bioactive compounds contents and antioxidant activities of Anthriscus sylvestris (L.) Hoffm., Polygonum cognatum Meissn., Rumex crispus L., Allcemilla sericata Rchb. and Primula veris L. grown in the Ardahan centre located in the North East Anatolia Region of our country. The areal parts collected in May, brought to the laboratory and the analysis were performed with extracts prepared from fresh samples. The highest total phenolic, total flavonoid contents, 2,2'-azino-bis(3ethylbenzothiazoline-6-sulfonic acid (ABTS) (\% 91.9), 2,2-diphenyl-1-picrylhydrazyl (DPPH) (\% 58.9) and Ferric Reducing Antioxidant Power (FRAP) (770.8 umol Fe II/g) activities was detected in Allcemilla sericata Rchb. It was determined that total ascorbic acid contents of plant species was between 118.5 and $387.7 \mathrm{mg} / 100 \mathrm{~g}$, Anthriscus sylvestris (L.) had the highest total ascorbic acid content.
\end{abstract}

Keywords: Antioxidant, ascorbic, phenolic, flavonoid, medical plant.

\title{
1. Giriş
}

Bitkiler zengin biyoaktif bileșen içeren kaynaklardır. Birçok bitki yapısındaki bu bileşenlerden ötürü ilaç yapımında kullanılmaktadır. Aynı zamanda tıbbi özellikteki bu bitkilerin kendisi veya saf bitkisel bileşenleri de tedavi veya koruma amaçli kullanılmaktadır. Bitkilerde bulunan terpenler, alkaloidler, fenil propanoidler ve flavanoidler gibi maddeler sekonder metabolit olarak adlandırılmakta ve birçoğu ilaç olarak kullanılmaktadır. Papaver sp. türlerinde bulunan morfin, Artemisia sp. türlerinde bulunan artemisin veya Glycine max L. türünde bulunan genistein bu bileşenlere örnek olarak verilebilir [1]. Tıbbi bitkilerin tedavi amaçlı kullanımının yaklaşık 50,000 yıllık tarihi olduğu düşünülmektedir [2]. Dünya Sağlık Örgütü (WHO) [3] özellikle az gelişmiş ülkelerde yaşayan insanların \% 80'inden fazlasının bitkisel tedavi yöntemlerini kullandığını bildirmiştir. Dünya genelinde 1990'lı yıllardan sonra doğal ürünlere olan talebin artışıyla birlikte tıbbi bitkiler önem kazanmıştır. Günümüzde tıbbi bitkiler piyasasının yıllık yaklaşık 60 milyar dolarlık bir rakama sahip olduğu tahmin edilmektedir [4].

Ülkemiz çok zengin bir bitki örtüsüne sahiptir. Ülkemizde tıbbi amaçlı kullanılan bitki sayısı tam olarak bilinmemekle birlikte 500 civarında olduğu tahmin edilmektedir [5]. Bu bitkilerden bazıları Anthriscus sylvestris (L.) Hoffm., Polygonum cognatum Meissn., Rumex crispus L., Allcemilla sericata Rchb. ve Primula veris L.' dır.

\subsection{Kımı (Anthriscus sylvestris L. Hoffm.) bitkisi}

Anthriscus sylvestris L. Apiaceae familyasına ait yabani bir bitki türüdür [6]. Yapısında terpenoid, fenolik, flavanoid yapıda birçok bileşen içerdiği belirlenmiştir [7]. Bitki ağrı kesici, idrar söktürücü, ateş düşürücü ve öksürük kesici olarak bilinmektedir [8]. Aynı zamanda antimikrobiyal ve antitümör özellikte olduğu da bildirilmiştir [9]. Bitki Kuzeydoğu Anadolu Bölgesinde yemeği, turşusu ve çorbası yapılarak tüketilmektedir. Aynı zamanda bitkinin toprak altı kısmındaki yumrular atol olarak adlandırılmakta, kabuğu soyularak; çiğ veya pişmiş halde tüketilmektedir. 


\subsection{Madımak (Polygonum cognatum Meissn.) bitkisi}

Latince adı Polygonum cognatum olan madımak bitkisi Türkiye'nin birçok bölgesinde yetişmekte, son zamanlarda tarımı da yapılmaktadır [10]. Gövdesi toprak üstünde yatay duran, pembe çiçekli, elips şeklinde yaprakları olan kısa saplı bir bitkidir [11]. Halk arasında bezmece otu, kuşekmeği, kuşdili, kuş pidesi, çoban ekmeği gibi adlarla da adlandırılmaktadır [12]. Bitki zengin fenolik içeriğine sahiptir [13]. Bitkinin idrar söktürücü ve kan glikoz seviyesini düşürücü etki yaptığı bildirilmiştir [14]. Ülkemizin birçok bölgesinde yemeği yapılarak tüketilmektedir. Bitkinin genç sürgünleri kurutularak veya konservesi yapılarak saklanmaktadır.

\subsection{Evelik (Rumex crispus L.) bitkisi}

Polygonaceae familyasının bir üyesi olan Rumex crispus kültürü yapılmadığı halde dünyanın birçok yerinde geniş bir yayılım alanına sahip bir bitkidir [15]. Bitkinin çiçek, kök ve yaprakları ağrı, egzama, sindirim problemleri, soğuk algınlığı, grip, ateş gibi rahatsızlıkların tedavisinde kullanılmaktadır [5]. Ayrıca bitkinin kök ekstraktlarının romatizmal hastalıkların ve hemoroidin tedavisinde kullanıldığı, laksatif ve kan temizleyici olduğu bildirilmiştir [16]. Bitkinin genç yaprakları ilkbahar aylarında toplanarak sebze olarak tüketilmektedir [5].

\subsection{Aslan Pençesi (Allcemilla sericata Rchb.) bitkisi}

Rosaceae familyasında yer alan Alchemilla L. cinsinin dünyada 1000'den fazla türü mevcuttur. Bu taksonlardan yaklaşık 50'si Türkiye florasında doğal olarak yetişmektedir. 8 taksonun ise endemik olduğu bilinmektedir [17, 18]. Aslanpençesi bitkisi Anadolu'da halk tıbbında sıklıkla kullanılan bir bitkidir. Bitkinin özellikle yaprakları ve çiçekleri kullanılmaktadır [19]. Bitki genellikle dermatolojik ve kozmetik amaçlarla, çiçeklenme periyodu boyunca, Mayıs ayından Haziran ayının sonuna kadar toplanmaktadır. Bitki ayrıca yaraların, egzamanın, iltihaplı dokuların tedavisinde kullanılmaktadır [20].

\subsection{Cuha (Primula veris L.) bitkisi}

Primulaceae familyasının bir üyesi olan Primula veris' in yaprak, kök ve çiçeklerinin farmakolojik özelliklere sahip olduğu uzun yıllardır bilinmektedir. Bitki halk tarafından idrar söktürücü, antimikrobiyal, antifungal, sedatif, iltihap giderici ve balgam söktürücü olarak kullanılmaktadır. Aynı zamanda bitkinin çiçekleri ve köklerinin fenolik asitler ve flavanoidler yönünden zengin olduğu, bronşit, öksürük ve nezleye karşı kullanıldığı bilinmektedir [21, 22].

$\mathrm{Bu}$ çalışmanın amacı Ardahan bölgesinde yetişen bazı tıbbi bitkilerin (Anthriscus sylvestris, Polygonum cognatum, Rumex crispus, Allcemilla sericata ve Primula veris) bazı biyokimyasal içerikleri ile antioksidan aktivitelerinin belirlenmesidir.

\section{Materyal ve metot}

\subsection{Bitki materyali}

Anthriscus sylvestris, Polygonum cognatum, Rumex crispus, Allcemilla sericata ve Primula veris bitkilerinin toprak üstü kısımları Mayıs ayında Ardahan Çamlıçatak mevkiinden toplanmıştır (Tablo 1). Bitkilerin sistematik teşhisleri Flora of Turkey and The East Aegean Island'a göre yapılmıştır [23]. Analiz için toplanan örnekler polietilen torbalar içerisinde laboratuara getirilerek ekstrakt hazırlanıncaya kadar $+4{ }^{\circ} \mathrm{C}$ de bekletilmiştir. 
Tablo 1. Örneklerin toplandığı kordinat, lokalite ve rakımlar.

\begin{tabular}{|c|c|c|c|}
\hline & Kordinat & Lokalite & Rakım(m) \\
\hline $\begin{array}{l}\text { Anthriscus sylvestris (L.) } \\
\text { Hoffm }\end{array}$ & $\begin{array}{l}\text { N } 41^{0} 07^{\prime} 46,5^{\prime}, \\
\text { E } 42^{0} 47^{\prime} 17,5^{\prime}\end{array}$ & Çamlıçatak/Ardahan & 1902 \\
\hline Polygonum cognatum Meissn. & $\begin{array}{l}\text { N } 41^{\circ} 07^{\prime} 42,6^{\prime}, \\
\text { E } 42^{\circ} 47^{\prime} 12,9^{\prime}\end{array}$ & Çamliçatak/Ardahan & 1903 \\
\hline Rumex crispus L. & $\begin{array}{l}\text { N } 41^{\circ} 07^{\prime} 42,2^{\prime \prime}, \\
\text { E } 42^{0} 47^{\prime} 14,9^{\prime}\end{array}$ & Çamlıçatak/Ardahan & 1903 \\
\hline Allcemilla sericata Rchb. & $\begin{array}{l}\text { N } 41^{\circ} 07^{\prime} 42,0^{\prime}, \\
\text { E } 42^{0} 47^{\prime} 24,2^{\prime}\end{array}$ & Çamlıçatak/Ardahan & 1891 \\
\hline Primula veris $\mathrm{L}$. & $\begin{array}{l}\text { N } 41^{\circ} 07^{\prime} 44,3^{\prime \prime} \\
\text { E } 42^{0} 47^{\prime} 25,2^{\prime}\end{array}$ & Çamlıçatak/Ardahan & 1892 \\
\hline
\end{tabular}

\subsection{Bitki ekstraktlarının hazırlanması}

Taze örnekler küçük parçalara ayrılmış ve $2 \mathrm{~g}$ bitki örneği $20 \mathrm{ml}$ metanol ile homojenize edilmiş ve 24 saat çalkalamalı etüvde, $4{ }^{\circ} \mathrm{C}$ 'de bekletilmiştir. Daha sonra $10 \mathrm{dk} 5000$ rpm'de santrifüj edilmiştir. Alınan süpernatan toplam fenolik madde, toplam flavanoid madde ve antioksidan kapasite analizlerinde kullanılmıştır. Askorbik asit tayini için aynı ekstraksiyon metodu uygulanmış ancak çözücü olarak okzalik asit kullanılmıştır.

\subsection{Toplam fenolik madde tayini}

Toplam fenolik madde tayini Spanos ve Wrolstad [24]'a göre Folin-Ciocalteu yöntemi kullanılarak belirlenmiştir. $200 \mu \mathrm{l}$ ekstrakt, $1000 \mu \mathrm{l}$ folin-ciocalteu ve $800 \mu \mathrm{l}$ (\% 7.5) $\mathrm{Na}_{2} \mathrm{CO}_{3}$ cam tüp içerisine eklenerek karışım oda sıcaklığında 2 saat inkübasyona bırakılmıştır. Süre sonunda absorbans spektrofotometrede 750 nm'de \% 50 etanol-su karışımına karşı ölçülmüştür. Örneklerin toplam fenolik madde içerikleri gallik asit standardı kullanılarak mg/100 g cinsinden hesaplanmıştır.

\subsection{Toplam flavonoid madde tayini}

Toplam flavanoid madde tayini Quettier ve ark. [25]'nın yöntemine göre belirlenmiştir. $1 \mathrm{ml}$ ekstrakt $1 \mathrm{ml} \% 2$ 'lik $\mathrm{AlCl}_{3}$ ile karıştırılarak, oda sıcaklığında ve karanlıkta 1 saat inkübe edilmiştir. Örneklerin absorbansı $415 \mathrm{~nm}$ 'de spektrofotometre ile belirlenmiş ve rütin standardı kullanılarak hazırlanmış olan kalibrasyon eğrisinden yararlanılarak $\mathrm{mg} / 100 \mathrm{~g}$ cinsinden hesaplanmıştır.

\subsection{Toplam askorbik asit tayini}

Toplam askorbik asit tayini Şahin [26]'e göre spektrofotometrik yöntemle belirlenmiştir. Bir cam tüpe $100 \mu$ l süpernatant $400 \mu \mathrm{L} \%$ 0,4'lük okzalik asit ve 4,5 ml 2,6-diklorofenolindofenol çözeltisi eklenmiş ve absorbans değerleri $520 \mathrm{~nm}$ 'de spektrofotometrik olarak belirlenmiştir. Örneklerdeki askorbik asit miktarı kalibrasyon grafiği kullanılarak mg/100 g cinsinden hesaplanmıştır.

\subsection{Antioksidan kapasite tayini}

Örneklerin antioksidan kapasiteleri DPPH (2,2-diphenyl-1-picryl-hydrazyl-hydrate), ABTS (2,2-Azino-bis-3-ethylbenzothiazoline-6-sulfonic Acid) ve FRAP (Ferric Reducing Antioxidant Power) yöntemleri kullanılarak belirlenmiştir.

\subsubsection{DPPH metodu}

$4 \mathrm{ml}$ DPPH solüsyonu $(0,1 \mathrm{~N}) 1 \mathrm{ml}$ ekstrakt ile birleştirilerek, $30 \mathrm{dk}$ karanlık bir ortamda, oda sıcaklığında, çalkalayıcıda bekletilmiştir. Absorbans ölçümleri 
spektrofotometrede $515 \mathrm{~nm}$ 'de yapılmıştır. Antioksidan kapasite \%DPPH=(AkontrolAörnek)/Akontrol x100 formülüyle hesaplanmıştır [27, 28].

\subsubsection{ABTS metodu}

ABTS yöntemi Re ve ark. [29]'na göre yapılmıştır. $7 \mathrm{mM}$ ABTS ve 2,45 mM potasyum per sülfat ile 1:1 oranında stok solüsyon hazırlanmış ve 16 saat oda sıcaklığında karanlık ortamda inkübe edilmiştir. Analizler için stok solüsyon absorbansı 734 nm'de $0,7 \pm 0,05$ olana kadar etanolle dilüe edilmiştir. $150 \mu 1$ örnek 2,85 ml ABTS solüsyonuyla karıştırılmış ve $6 \mathrm{dk}$ oda sıcaklığında inkübe edildikten sonra $734 \mathrm{~nm}$ 'de absorbansı ölçülmüştür. Antioksidan kapasite \%ABTS=(Akontrol-Aörnek)/Akontrol x 100 formülüyle hesaplanmıştır.

\subsubsection{FRAP metodu}

FRAP yöntemi Benzie ve Strain [30]'e göre yapılmıştır. FRAP ajanı $25 \mathrm{ml}$ sodyum asetat tamponu (300 mM, pH3,6), $2.5 \mathrm{ml}$ TPZT solüsyonu (40 mM HCl içerisinde10 $\mathrm{mM})$ ve $2,5 \mathrm{ml} \mathrm{FeCl}{ }_{3} 6 \mathrm{H}_{2} \mathrm{O}(20 \mathrm{mM})$ karışımıyla hazırlanmıştır. Ajan $37^{\circ} \mathrm{C}$ 'de su banyosunda 1lıtılmış ve $900 \mu \mathrm{l}$ 'si bir küvete alınarak başlangıç absorbans değeri okunmuştur. Dilüe (1:4 v/v su) örneğin $100 \mu \mathrm{l}$ 'si küvete alınmış ve üzerine $3 \mathrm{ml}$ FRAP ajanı eklenmiştir. $4 \mathrm{dk}$ sonra absorbans 593 nm'de ölçülmüştür. Standart eğri $\mathrm{FeSO}_{4}$ solüsyonu kullanılarak hazırlanmıştır (100-1000 $\mu$ l). Sonuçlar $\mu$ mol Fe (II)/g cinsinden hesaplanmıştır.

\subsection{Veri analizleri}

Çalışmada her bir analiz üç tekrar şeklinde yapılmıș ve ortalama değerleri alınmıştır. Örneklerin ortalama değerleri ve standart sapmaları SPSS 16,0 paket programı aracılığ ile hesaplanmıştır. Gruplar arasındaki farklılıklar Duncan [31] çoklu karşılaştırma testi ile $\mathrm{p}<0,05$ önem düzeyinde belirlenmiştir.

\section{Bulgular ve tartışma}

Fenolik bileşikler bir halkaya bağlı bir veya birden fazla hidroksil grubu içermektedirler. $\mathrm{Bu}$ yapıları sayesinde radikal süpürücü yeteneğe sahiptirler [32]. Fenolik bileşiklerin insanlarda mutagenez ve kanser oluşumuna karşı koruyucu etkisinin olduğu bilinmektedir [33]. Bu özelliklerinden dolayı fenolikler bitkilerin en önemli bileşenlerindendir. Bitki örneklerinin toplam fenolik, toplam flavanoid ve toplam askorbik asit içerikleri Tablo 2'de gösterilmiştir. Farklı bitki örneklerinin toplam fenolik madde içerikleri istatistiksel olarak anlamlı bulunmuştur $(\mathrm{p}<0,05)$. Bitki ekstraktlarının toplam fenolik madde içerikleri 80,7 ile 427,2 mg/100g değerleri arasında değişmektedir. En yüksek içerik A. sericata'da en düşük içerik ise R.crispus'ta belirlenmiştir. Demir ve ark. [34] P.veris etanol ekstraktlarında toplam fenolik madde içeriğinin 122,8 $\mu \mathrm{g} / \mathrm{g}$ olduğunu tespit etmiştir. Araştırıcılar bu ekstraktlardaki fenolik madde ile antioksidan kapasite arasında ilişki bulamamışlardır. Başka bir çalışmada $A$. sericata kurutulmuş bitkisinin ekstraktlarında fenolik madde içeriği 96,43 mg/g olarak bildirilmiştir [35]. Çoruh ve ark. [36] R.crispus'un kurutulmuş toprak üstü kısmının ekstraktlarında fenolik madde içeriğinin $56,31 \mu \mathrm{g} / \mathrm{mg}$ olduğunu tespit etmişlerdir. 
Tablo 2. Bitki örneklerinin bazı biyoaktif bileșenleri.

\begin{tabular}{|c|c|c|c|}
\hline & $\begin{array}{l}\text { Toplam Fenolik } \\
\text { Madde Miktarı } \\
\quad(\mathrm{mg} / \mathbf{1 0 0 g})\end{array}$ & $\begin{array}{c}\text { Toplam } \\
\text { Flavanoid } \\
\text { Madde Miktarı } \\
(\mathbf{m g} / \mathbf{1 0 0 g})\end{array}$ & $\begin{array}{c}\text { Toplam } \\
\text { Askorbik asit } \\
\text { Miktarı } \\
(\mathbf{m g} / \mathbf{1 0 0 g})\end{array}$ \\
\hline Anthriscus sylvestris (L.) Hoffm. & $290,1 \pm 9,4 \mathrm{~b}$ & $23,2 \pm 1,1 \mathrm{a}$ & $387,7 \pm 25,2 \mathrm{a}$ \\
\hline Polygonum cognatum Meissn. & $223,6 \pm 11,4 b$ & $26,17 \pm 1,4 \mathrm{a}$ & $211 \pm 2,5 \mathrm{c}$ \\
\hline Rumex crispus L. & $80,7 \pm 6,6 \mathrm{~d}$ & $26,60 \pm 1,8 \mathrm{a}$ & $246,8 \pm 61,4 \mathrm{~b}$ \\
\hline Allcemilla sericata $\mathrm{Rchb}$. & $427,2 \pm 13,3$ a & $29,52 \pm 1,2 \mathrm{a}$ & $257,7 \pm 68,7 b$ \\
\hline Primula veris $\mathrm{L}$. & $172,7 \pm 16,4 \mathrm{c}$ & $22,88 \pm 2,7 \mathrm{a}$ & $118,5 \pm 37,7 \mathrm{~d}$ \\
\hline
\end{tabular}

Tıbbi bitkiler flavanoidler gibi bazı sekonder metabolitleri doğal olarak çeşitli amaçlar için üretmekte ve bünyelerinde biriktirmektedirler [37]. Flavanoidler günlük diyetle büyük miktarlarda tüketilmektedirler. Bu maddelerin antiinflamatuar, antibakteriyel, antiviral, antialerjik ve antitümör etkilere sahip oldukları bildirilmiştir [38]. Tablo 2' de görüldüğü gibi bitki örneklerinin toplam flavanoid madde içerikleri istatistiksel olarak önem arz etmemektedir. En yüksek değer $A$. sericata'da $(29,52 \mathrm{mg} / 100 \mathrm{~g})$, en düșük değer ise P.veris'te $(22,88 \mathrm{mg} / 100 \mathrm{~g})$ belirlenmiştir. Ding ve ark. [39] A.vulgaris'in flavanoid, fenol, tanen ve saponin gibi sekonder metabolitleri içerdiğini tespit etmişler ve bitkide en fazla bulunan bileşiğin flavanoidler olduğunu bildirmişlerdir. Denev ve Kratchanova [40] A. sericata'nın metanolik ekstraktlarında toplam flavanoid madde içeriğinin $1,83 \mathrm{~g} / 100 \mathrm{~g}$ olduğunu bulmuşlardır. Rudhani ve ark. [41] farklı P.veris ekstraktlarının toplam fenolik madde ve toplam flavanoid madde içeriklerinin sırasıyla 5,10 ile $17,30 \mathrm{mg} / \mathrm{g}, 12,15$ ile $31,43 \mathrm{mg} / \mathrm{g}$ değerleri arasında olduğunu bildirmişlerdir. Bir diğer literatürde ise kurutulmuş A.sylvestris yaprak etanolik ekstraktlarında toplam fenolik madde ve toplam flavanoid madde içeriklerini sırasıyla $41,63 \mathrm{mg} / \mathrm{g}$ ve 25,76 $\mathrm{mg} / \mathrm{g}$ olarak bulmuşlardır [42].

Bizim çalışmamızda elde ettiğimiz sonuçların daha önceki araştırma sonuçlarına göre daha düşük olmasının en önemli nedeninin taze bitki örnekleriyle çalışmamız olduğu düşünülmektedir. Aynı zamanda çözücü farklılıkları, bitkinin yetişme şartları gibi faktörler de sonucu etkileyebilmektedir.

Birçok bitki bol miktarda askorbik asit içermektedir. Bu çeşit bitkiler çiğ olarak tüketildiklerinde çok iyi birer $\mathrm{C}$ vitamini kaynaklarıdırlar. Askorbik asit serbest radikal azaltıcı yeteneğinden dolayı iyi bir antioksidan olarak bilinmektedir [43]. Bu çalışmada bitki ekstraktlarının toplam askorbik asit içeriklerinin $118,5 \mathrm{mg} / 100 \mathrm{~g}$ (P.veris) ve 387,7 mg/100g (A.sylvestris) değerleri arasında olduğu belirlenmiştir. Meos ve ark. [44] P.veris'in taze yapraklarının kuru yapraklarından çok daha fazla askorbik asit içerdiğini bildirmişlerdir. Ryabova [45] bu bitkinin yapraklarının çok zengin bir askorbik asit kaynağı olduğunu rapor etmiştir. Yine daha önce yapılan bir çalışmada kurutulmuş P.cognatum ekstraktlarının 86,21 mg/100 g askorbik asit içerdiği bildirilmişstir [11]. Genel olarak daha önceki çalışmalarla kıyaslama yaptığımızda, bizim çalışmamızda askorbik asit değerinin daha yüksek olduğu görülmüştür. Bu durumun taze örnekle çalışmamızdan kaynaklandığı düşünülmektedir. Çünkü askorbik asitin kurutma boyunca uygulanan sıcaklıklardan etkilenerek bozulduğu bilinmektedir [44]. 
Örneklerin antioksidan aktivite sonuçları Tablo 3'de verilmiştir. Çalışmada antioksidan aktiviteler üç farklı metotla (ABTS, FRAP ve DPPH) belirlenmiştir. Her üç metodun sonuçlarının da fenolik madde ve flavanoid madde sonuçlarıyla doğru orantılı olduğu tespit edilmiştir. Antioksidan parametre değerlerinde bitkiler arasında istatistiksel olarak önemli varyasyonlar tespit edilmiştir $(\mathrm{p}<0,05)$. Her üç metoda göre de $A$. sericata'nın en yüksek (ABTS: \%91,9, FRAP:770,8 $\mu$ molFe (II)/g ve DPPH: \%58,9) antioksidan aktiviteye, P.cognatum'un ise en düşük ABTS değerine (62.9\%) sahip olduğu belirlenmiştir. Bununla birlikte R.crispus en düşük FRAP $178,4 \mu \mathrm{molFe}(\mathrm{II}) / \mathrm{g}$ ) ve A.sylvestris en düşük DPPH $(\% 32,4)$ değerlerine sahiptirler. Daha önce yapılan birkaç çalışmadaki sonuçlar bizim bulduğumuz değerlere benzemektedir. Hamid ve ark. [35] kurutulmuş A.vulgaris bitkisinin TEAC ve FRAP değerlerinin 68,21 ve 40,12 $\mathrm{mmol} / \mathrm{g}$ olduğunu, Baş ve Pandır [46] ise P.cognatum'un su ekstraktlarının FRAP değerinin 5,142 $\mu \mathrm{mol} / \mathrm{L}$, TEAC değerinin 104,45 $\mu \mathrm{mol} / \mathrm{L}$ olduğunu rapor etmişlerdir.

Tablo 3. Bitki örneklerinin antioksidan kapasite değerleri.

\begin{tabular}{lccc}
\hline & $\begin{array}{c}\text { ABTS } \\
(\boldsymbol{\%})\end{array}$ & $\begin{array}{c}\text { FRAP } \\
(\boldsymbol{\mu} \mathbf{m o l ~ F e ~ I I / g )}\end{array}$ & $\begin{array}{c}\text { DPPH } \\
(\boldsymbol{\%})\end{array}$ \\
\hline Anthriscus sylvestris (L.) Hoffm. & $77,8 \pm 6,1 \mathrm{~b}$ & $331,7 \pm 23,2 \mathrm{c}$ & $32,4 \pm 7,9 \mathrm{c}$ \\
Polygonum cognatum Meissn. & $62,9 \pm 0,3 \mathrm{c}$ & $602,3 \pm 38,4 \mathrm{~b}$ & $46,2 \pm 0,9 \mathrm{~b}$ \\
Rumex crispus L. & $63,6 \pm 7,2 \mathrm{c}$ & $178,4 \pm 17,2 \mathrm{~d}$ & $39,9 \pm 2,2 \mathrm{c}$ \\
Allcemilla sericata Rchb. & $91,9 \pm 0,2 \mathrm{a}$ & $770,8 \pm 11,9 \mathrm{a}$ & $58,9 \pm 3,6 \mathrm{a}$ \\
Primula veris L. & $88 \pm 1,5 \mathrm{a}$ & $757,2 \pm 11,4 \mathrm{a}$ & $34,2 \pm 0,2 \mathrm{c}$ \\
\hline
\end{tabular}

Aynı sütunda gösterilen farklı harfler (a-d) Duncan çoklu karşılaştırma testine göre istatistiksel olarak

farklılıkları göstermektedir $(\mathrm{p}<0.05)$.

Çalışma sonucunda bölgede yetişen 5 farklı türün özellikle de A. sericata (aslan pençesi) bitkisinin yüksek biyoaktif bileşenlere ve antioksidan kapasiteye sahip oldukları belirlenmiştir. Günümüzde oksidatif stres kaynaklarının ve buna bağlı olarak da birçok hastalığın aşırı derecede çoğalması düşünüldüğünde bu bitkilerin ve bu tür çalışmaların ne kadar önemli olduğu görülmektedir. Halk tarafından sıklıkla yiyecek veya tıbbi amaçlı olarak kullanılan bu bitkilerin kromatografik metotlarla daha ayrıntılı olarak çalışılması gerekmektedir.

\section{Kaynaklar}

[1] Hendrawati, O., Studies on Anthriscus sylvestris L. (Hoffm.) Metabolic engineering of combinatorial biosynthesis of podophyllotoxin, pHD Thesis, Groningen University, Holland, (2011).

[2] Özbek, H., Cinsel ve Jinekolojik Sorunların Tedavisinde Bitkilerin Kullanımı, Van Tıp Dergisi, 12(2), 170-174, (2005).

[3] Dünya Sağlık Örgütü (2014) http://www.who.int/en/ (Erişim Tarihi: 19.12.2016)

[4] Kumar, S.A., Plants-based Medicines in India http://pib.nic.in/feature/feyr2000/fmay 2000/f240520006.html. Erişim Tarihi: 12.08.2016.

[5] Baytop, T., Türkiye'de Bitkiler ile Tedavi, Geçmişte ve Bugün. Nobel Tıp Kitabevleri, İstanbul, s.480, (1996).

[6] Spalık, K., Typification of the Boissier names in Anthriscus Pers. (Apiaceae). Botanican Journal of The Linnean Society, 119(1), 77-86, (1995). 
[7] Jeong, G.S., Kwon, O.K., Park, B.Y., Oh, S.R., Ahn, K.S., Chang, M.J., Oh, W.K., Kım, J.C., Min, B.S., Kım, Y.C., ve Lee, H.K., Lignans and coumarins from the roots of Anthriscus sylvestris and their increase of caspase-3 activity in HL-60 cells, Biological and Pharmaceutical Bulletin, 30, 1340-1343, (2007).

[8] Chen, H., Jiang, H.Z., Li, Y.C., Wei, G.Q. , Geng, Y., ve Ma, C.Y., Antitumor constituents from Anthriscus sylvestris (L.) Hoffm, Asian Pacific Journal of Cancer Prevention, 15, 2803-2807, (2014).

[9] Jung, C.H., Kım, H., Ahn, J., Jung, S.K., Um, M.Y., Son, K.H., ve Ha, T.Y., Anthricin Isolated from Anthriscus sylvestris (L.) Hoffm. Inhibits the Growth of Breast Cancer Cells by Inhibiting Akt/mTOR Signaling, and Its Apoptotic Effects Are Enhanced by Autophagy Inhibition, Evidence-Based Complementary and Alternative Medicine, 385219, (2013).

[10] Onen, H., Parmaksız, I. ve Gebologlu, N., Reproduction capacity of Polygonum cognatum Meissn. (Knotweed). ASA, CSSA, and SSSA International Annual Meetings, San Antonio, TX, (2011).

[11] Demir, H., Erzurum'da yetişen madımak, yemlik ve kızamık bitkilerinin bazı kimyasal bileşimi, Bahçe, 35(1-2), 55-60, (2006).

[12] Tuzlac1, E., Türkiye'nin yabani besin bitkileri ve ot yemekleri, Melisa Matbaacılık, İstanbul, (2011).

[13] Onen, H., Y1lar, M. ve Kaya, C., Phenoleic composition of madimak (Polygonum cognatum Meissn.) plants. 3. Plant protection Congress. Van, Turkey, (2009).

[14] Asımgil, A., Şifalı Bitkiler. Timaş yayınları, İstanbul, (2003).

[15] Hughes, E.W., Studies into the biology of some Rumex species, MSc thesis, University of Wales, Cardiff, UK, (1938).

[16] Yildirim, A., Mavi, A., ve Kara, A.A., Determination of antioxidant and antimicrobial activities of Rumex crispus L. extracts, Journal of Agricultural and Food Chemistry, 49(8), 4083-4089, (2001).

[17] Hayırlıglu-Ayaz, S., ve Inceer, H., Three new Alchemilla L. (Rosaceae) records from Turkey, Pakistan Journal of Botany, 41(5), 2093-2096, (2009).

[18] Kaya, B., Menemen, Y., ve Saltan, F.Z., Flavonoids in the endemic species of Alchemilla L., (section Alchemilla L. subsection Calycanthum Rothm. Ser. Elatae Rothm.) from North-east Black Sea Region in Turkey, Pakistan Journal of Botany, 44(2), 595-597, (2012).

[19] Gruenwald, J., Brendler, T., ve Jaenicke, C. (Eds), Physician's Desk Reference (PDR) for Herbal Medicines, Thomson PDR, Montvale, 497, (2004).

[20] Eggensperger, H., Zur Anwendung pfl anzlicher Gerbstoffe in der Dermatologie und Kosmetik. In: Multiaktive Wirkstoffe für Kosmetika (Eggensperger H., ed.). Verlag für chemische Industrie, Augsburg, 107-127, (2006).

[21] Gamze, B. Ozmen A., Biyik, H. H. ve Şen, O., Antimitotic and antibacterial effects of the Primula veris L. flower extracts, Caryologia, 61(1), 88-91, (2008).

[22] EMA (European Medicines Agency), Assessment report on Primula veris L. and/or Primula elatior (L.) Hill, flos,” EMA/HMPC/136583/2012, (2012).

[23] Davis, P.H. Flora of Turkey and the East Aegean Islands. Edinburgh: Edinburgh University Press, 3, 328-369, (1970).

[24] Spanos, G.A., ve Wrolstad, R.E., Phenolic of apple, pear and white grape juices and their changes with processing and storage, Journal of Agriculture and Food Chemistry, 40(9), 1478-1487, (1992). 
[25] Quettier-Deleu, C., Gressier, B., Vasseur, J., Dine, T., Brunet, J., Luyck, M., Cazin, M., Cazin, J.C., Bailleul, F., ve Trotin, F., Phenolic compounds and antioxidant activities of buckwheat (Fagopyrum esculentum Moench) hulls and flour, Journal of Ethnopharmacology, 72, 35-40, (2000).

[26] Şahin, G., Dondurarak ve açık havada kurutarak muhafazanın kuşburnu meyvesinin bazı kalite özelliklerine etkileri, Yüksek Lisans Tezi, Gaziosmanpaşa Üniversitesi, Fen Bilimleri Enstitüsü, (2013).

[27] Bakhshi, D., ve Arakawa, O., Effects of UV-b irradiation on phenolic compound accumulation and antioxidant activity in 'Jonathan' apple influenced by bagging, temperature and maturation, Journal of Food, Agriculture \& Environment, 4(1), 75-79, (2006).

[28] Rezaeirad, D., Bakhshi, D., Ghasemnezhad, M., ve Lahiji, H.S., Evaluation of some quantitative and qualitative characteristics of local pears (Pyrus sp.) in the North of Iran, International Journal of Agriculture and Crop Sciences, 5(8), 882-887, (2013).

[29] Re, R., Pellegrini, N., Proteggente, A., Pannala, A., Yang, M., ve Rice-Evans, C., Antioxidant activity applying an improved ABTS radical cation decolorization assay, Free Radical Biology and Medicine, 26(9-10), 12311237, (1999).

[30] Benzie, I.F.F, ve Strain, J.J., The ferric reducing Ability of plasma (FRAB) as a measure of Antioxidant power: The FRAB assay, Analytical Biochemistry, 239, 70-76, (1996).

[31] Duncan, D.B., Multiple range and multiple F Tests, Biometrics, 11, 1-14, (1955).

[32] Mitsuda, H., Yuasumoto, K., ve Iwami, K., Antioxidation action of indole compounds during the autoxidation of linoleic acid, Eiyo to Shokuryo, 19, 210214, (1996).

[33] Celik, H., Kucukoglu, K., Nadaroglu, H., ve Senol, M., Evaluation of antioxidant, antiradicalic and antimicrobial activities of kernel date (Fructus dactylus), Journal of Pure and Applied Microbiology, (2014).

[34] Demir, N., Alayli Güngör, A., Güngör Nadaroglu, H. ve Demir, Y., The antioxidant and radical scavenging activities of Primrose (Primula vulgaris), European Journal of Experimental Biology, 4(2), 395-401, (2014).

[35] Hamid, K.H.A., Azman, N.A.M., Sharaani, S., Zain, N., Ahmad, N., Sulaiman, A.Z., Chik, S.S.T., Ishak, W.F.W., ve Pablos, M.P.A., Alchemilla vulgaris and Filipendula ulmaria Extracts as Potential Natural Preservatives in Beef Patties, Malaysian Journal of Analytical Sciences, 21(4), 986-995, (2017).

[36] Coruh, I., Gormez, A., Ercisli, S., ve Sengul, M., Total Phenolic Content, Antioxidant, and Antibacterial Activity of Rumex crispus Grown Wild in Turkey, Pharmaceutical Biology, 46(9), 634-638, (2008).

[37] Al-osaj, S.L., Cytotoxic Evaluation of Alchemilla vulgaris Flavonoids in Normal Blood lymphocytes, Master Thesis, Al-Nahrain University, (2016).

[38] Hanneken, A., Lin, F.F., Johnson, J., ve Maher, P., Flavonoids protect human retinal pigment epithelial cells from oxidative-stress-induced death, Investigative Ophthalmology and Visual Science, 47(7), 3164-77, (2006).

[39] Ding, W., Yang, T., ve Tian, S., Effect of different growth stages of Ziziphora clinopodioides Lam. on its chemical composition, Pharmacognosy Magazine, 10, 1-5, (2014).

[40] Denev, P., Kratchanova, M., Ciz, M., Lojek, A., Vasicek, O., Blazheva, D., Nedelcheva, P., Vojtek, L., ve Hyrsl, P., Antioxidant, antimicrobial and 
neutrophil-modulating activities of herb extracts, Polish Biochemical Society Journal, 61, 359-367, (2014).

[41] Rudhani, I., Raci, F., Ibrahimi, H., Mehmeti, A., Kameri, A., Faiku, F., Majlinda, M., Govori, S., ve Haziri, A., Phytochemical and in vitro Antioxidant Studies of Primula veris L. Growing Wild in Kosovo, Khimiya, 26(5), 773-785, (2017).

[42] Olaru, O.T., Nitulescu, G.M., Ortan, A., Babeanu, N., Popa, O., Ionescu, D., ve Dinu-Pirvu, C.E., Polyphenolic content and toxicity assessment of Anthriscus sylyestris Hoffm, Romanian Biotechnological Letters, 22, 6, (2016).

[43] Naidu, K.A., Vitamin $\mathrm{C}$ in human health and disease is still a mystery? An overview, Nutrition Journal, 2, 7-10, (2003).

[44] Meos, A., Zaharova, I., Kask, M., ve Raal, A., Contents of Ascorbic Acid in Common Cowslip (Primula veris L.) Compared to Common Food Plants and Orange Juices, Avta Biologica Cracoviensia Series Botanica, 59(1), 113-120, (2017).

[45] Ryabova, O., Primula officinalis L. as a source of vitamin C, Farmatsiya, 11, 22-24, (1939).

[46] Baş, H., Pandır D., Yozgat'ta Tarımı Yapılan ve Çokça Tüketilen Madımak (Polygonum Cognatum) Bitkisinin Antioksidan Kapasitesi ve $\mathrm{H}_{2} \mathrm{O}_{2}$ 'nin İnsan Eritrositlerinde Meydana Getirdiği in vitro Toksik Etki Üzerine Koruyucu Rolü, I.Uluslararası Bozok Sempozyumu, 05-07 Mayıs, Yozgat, (2016). 